\title{
GHARACTERISATION AND VARIATION OF AGARWOOD RESINS FROM GYRINOPS WALLA
}

\author{
de Alwis WNH ${ }^{1}$, Subasinghe SMCUP ${ }^{1} \&$ Hettiarachchi DS $^{2,3, *}$ \\ ${ }^{1}$ Centre for Forestry and Environment, Department of Forestry and Environmental Science, University of Sri \\ Jayewardenepura, Nugegoda, 10250 Sri Lanka \\ ${ }^{2}$ Phytocognosy, Harrisdale, WA, 6112 Australia \\ ${ }^{3}$ School of Science, Edith Cowan University, Joondalup, WA, 6027 Australia \\ *danny@phytocognosy.com.au
}

Submitted May 2018; accepted August 2018

\begin{abstract}
The genera Aquilaria and Gyrinops of Thymalaeaceae family produce agarwood as a response to damage to their xylem tissues. Agarwood is used for perfumery, incense and traditional medicine. Gyrinops walla is the only agarwood producing species naturally growing in Sri Lanka and it is often harvested illegally from the wild. Research on characteristics of the $G$. walla resin is limited and insufficient to support its development as an agroforestry crop. The present study sampled a total of $90 \mathrm{G}$. walla trees from nine natural populations distributed in four agro-ecological zones in Sri Lanka. Resinous tissues were collected and resin contents were solvent extracted. Yields varied from 0.1 to $9.8 \%$ with no significant difference between the populations. GC-MS analysis of the G. walla resin identified 21 constituents; agarospirol, $\delta$-selinene, alloaromadendrene oxide, spathulenol, and two unidentified 2-(2-phenylethyl) chromone derivatives were found to be common for all tested populations. The chemical composition of $G$. walla resins was comparable with commercially available agarwood resin of Aquilaria species. The average amount of agarospirol varied from 1.13 to $7.16 \%$. Significant correlations were not found between resin contents and tree diameter or height. Resin characteristics showed no significant difference between the populations. However, variations were observed among trees of the same population.
\end{abstract}

Keywords: Agarospirol, Thymalaeaceae, Sri Lanka, chromone derivatives, GC-MS

\section{INTRODUCTION}

Agarwood is a highly valuable, fragrant resin formed in the heartwood of certain genera of Thymalaeaceae family (Naef 2011). Several species of Aquilaria and Gyrinops are used to produce agarwood resins for commercial purposes. Trees of genera Aetoxylon and Gonystylus produce agarwood resin in their xylem tissue (Rasool \& Mohamed 2016), but they are not used commercially.

Agarwood is mainly used in perfumery and traditional medicine in East Asia. Agarwood resinous tissues are burnt to produce aroma with ritual as well as social significance in Asian, Indian and Middle Eastern cultures (van Beek \& Phillips 1999). High quality agarwood powder is prescribed in Chinese medicine as an analgesic, stomachic and expectorant; thus highly demanded by the herbalists (van Beek \& Phillips 1999). However, the greatest demand for the agarwood essential oil is in the perfumery industry. For centuries, it has been used as a key perfumery agent known as agar or oud in the Middle East and India. However, agarwood is now gaining popularity among western perfumery and other cosmetic industries (Tajuddin et al. 2016).

Agarwood resin is a phyto-alexin, which is produced as a response to an injury by the plant tissue (Akhsan et al. 2015, Wong et al. 2015). The Thymalaeaceae family possesses a unique defence mechanism to avoid further damage to the xylem tissue by producing agarwood oleoresin within the tree (Blanchette 2003). The undamaged or healthy xylem tissue of agarwood tree is pale in colour. However, with the resin formation, the mass and density of the affected wood are increased and the colour changes to dark brown or black (Rahman \& Basak 1980, Tajuddin et al. 2016). Scientists are yet to determine if the agarwood resin formation is triggered by biological or physical reasons (Poain \& Poain 2001, Turjaman et al. 2016). Current scientific 
findings suggest that resin formation is due to fungal species entering the tree upon physical or insect damage (Tamuli et al. 2000, Mohamed et al. 2010). Only about $10 \%$ of trees in their natural habitat form agarwood in a natural environment. The process is slow and is usually confined to an isolated part of the tree (Persoon 2007).

Agarwood aroma has been described as balsamic, spicy, woody and sweet, which is produced by sesquiterpenes, 2-(2-phenylethyl) chromone derivative and other volatile and semi-volatile compounds (Takemoto et al. 2008, Naef 2011, Rasool \& Mohamed 2016). Sesquiterpenes can be divided into oxygenated compounds and sesquiterpene hydrocarbons; however, categorising them according to the basic sesquiterpene structures is more beneficial for qualitative and quantitative analysis. Sesquiterpene classes (types) present in agarwood are agarofuran, vetispirane, cadinane, eremophilane or valencane, eudesmane or selinane, guaiene and prezizane (Naef 2011, Tajuddin et al. 2016). Geography, climate and soil conditions affect agarwood resin composition and these external factors could be more vital than inter-species differences (Gianno 1986, Soehartono \& Mardiastuti 1997, Pojanagaroon $\&$ Kaewrak 2005).

Gyrinops walla is the only agarwood producing species growing naturally in Sri Lanka. It grows to a height of $15 \mathrm{~m}$ with straight, slender trunk and small, rounded crown. Agarwood resins of G. walla were first recorded by our research group and subsequent studies have characterised the resin to be similar to commercial agarwood extracted from Aquilaria species (Subasinghe et al. 2012, Subasinghe \& Hettiarachchi 2013, 2015). These findings increased the awareness of the government and private sectors in Sri Lanka on the commercial value of this species. Gyrinops walla has limited distribution in the humid lowland forests and home gardens of the wet and intermediate zones of Sri Lanka (Dassanayake \& Fosberg 1981) due to population density and high agricultural activity. More recently, widespread poaching for valuable agarwood has destroyed the remaining resources. This study compared the regional variation of agarwood resins found in G. walla to find suitable populations for propagation and areas to establish plantations. Findings also help to establish a common chemical characterisation for G. walla as a source of agarwood.

\section{MATERIALS AND METHODS}

\section{Sampling and data collection}

This study used resins formed due to natural causes in trees growing in nine different populations and 10 trees were selected from each population. These populations were selected based on the natural habitat of G. walla, distributed in four agro-ecological zones (Somasekaran 1997) in Sri Lanka (Table 1).

Tree stems with visible physical damage were first tested using an increment borer to observe any resinous wood. Dark coloured resinous tissues were then carefully extracted by making fine incisions to the trunk in non-destructive manner. Height and diameter of trees, and the location and geographical condition of each site were also recorded.

\section{Resin extraction}

Resinous wood samples collected were dried in a convection air oven at $30{ }^{\circ} \mathrm{C}$ until a constant moisture level was recorded (total moisture

Table 1 Description of location of trees sampled for the study

\begin{tabular}{lllcc}
\hline Location & Agro-ecological region & Elevation $(\mathrm{m})$ & Annual rainfall $(\mathrm{mm})$ & Average temperature $\left({ }^{\circ} \mathrm{C}\right)$ \\
\hline Horawala & Wet low 1 (WL1) & $150-165$ & $>2540$ & $26-27$ \\
Kalatuwawa & Wet low 1 (WL1) & $130-140$ & $>2540$ & $26-27$ \\
Karandana & Wet low 1 (WL1) & $140-195$ & $>2540$ & $26-27$ \\
Maliboda & Wet low 1 (WL1) & $300-320$ & $>2540$ & $26-27$ \\
Neboda & Wet low 1 (WL1) & $180-205$ & $>2540$ & $26-27$ \\
Yagirala & Wet low 1 (WL1) & $40-80$ & $>1525$ & $26-27$ \\
Mirigama & Wet low 3 (WL3) & $55-70$ & $>3175$ & $27-28$ \\
Kalawana & Wet mid 1 (WM1) & $335-425$ & $>3175$ & $25-26$ \\
Suriyakanda & Wet up 1 (WU1) & $850-875$ & & $25-26$ \\
\hline
\end{tabular}

$\mathrm{n}=10$ per each location 
$10-12 \% \mathrm{w} / \mathrm{w})$. The wood samples were then ground using a grinder with cutter blades to obtain particle size $<2 \mathrm{~mm}$. An amount of 1.00 $\pm 0.01 \mathrm{~g}$ of the resinous wood was extracted by solvent maceration with three aliquots of $10 \mathrm{~mL}$ dichloromethane at 12-hour intervals. The combined extract was filtered (Whatman No. $1^{\mathrm{TM}}$ ) into a pre-weighed amber colour glass vial and evaporated under a stream of nitrogen gas. Resin extracts were kept in a desiccator for 24 hours before determining the resin content as weight percentage of resinous wood.

\section{Gas chromatography analysis for resin constituents}

Resin constituent analysis was conducted using gas chromatograph with mass selective detector equipped with HP-5MS $5 \%$ phenyl methyl siloxane capillary column $(30 \mathrm{~m} \times 0.25 \mathrm{~mm} \times 0.25 \mu \mathrm{m})$. Oven temperatures were 50 to $220{ }^{\circ} \mathrm{C}$ at $5{ }^{\circ} \mathrm{C} \min ^{-1}$ and held for $10 \mathrm{~min}$ at $220^{\circ} \mathrm{C}$. Injector temperature was kept at $250{ }^{\circ} \mathrm{C}$. Helium, the carrier gas, was kept at a flow rate of $2 \mathrm{~mL} \mathrm{~min}{ }^{-1}$. The interface temperature was set to $250{ }^{\circ} \mathrm{C}$. Split ratio was 1:10 and $1 \mu \mathrm{L}$ oil sample diluted to 1:1000 with anhydrous acetone was then injected into the column. Constituents were quantified by area normalisation method using the Chemstation ${ }^{\circledR}$ software.

Mass spectra were recorded at $70 \mathrm{eV}$ and the mass range was from mass-to-charge ratio $(\mathrm{m} / \mathrm{z})$ 33 to 550 atomic mass unit. The constituents were identified by the mass fragmentation pattern qualification based on National Institute of Standards and Technology 2008 Library and these were further verified by the published data on agarwood.

\section{Statistical analysis}

The differences in resin contents between populations were statistically tested by one-way ANOVA using MINITAB ${ }^{\odot} 14.0$ software. Resins extracted from $1 \mathrm{~g}$ of sample tissues were used for this analysis. Pearson's correlation test was used to identify the relationship of resin constituents with resin content and tree parameters measured. Relationship between different resin constituents were also identified using Person's correlation test.

\section{RESULTS}

\section{Tree diameter and height}

Diameter of the sampled trees varied from 8.0 to $48.0 \mathrm{~cm}$ while height varied from 6.0 to $22.0 \mathrm{~m}$ (results not shown). Due to high level of poaching, it was only possible to sample 3 trees of diameter $>40 \mathrm{~cm}$. There were 7 trees with diameters between 30.0 and $39.0 \mathrm{~cm}$ and 14 trees with diameters of 20.0 to $29.0 \mathrm{~cm}$. The remaining 66 trees had diameters $<20.0 \mathrm{~cm}$.

\section{Variation of resin content}

Agarwood content of $G$. walla trees varied from 0.1 to $9.8 \% \mathrm{w} / \mathrm{w}$ for all 90 trees in the selected populations (Figure 1). The highest average resin content $(4.9 \pm 1.4 \%)$ was recorded from Maliboda population while the lowest average resin content $(2.0 \pm 0.2 \%)$ was recorded from Yagirala (Figure 1). However, resin content between the selected populations was not significant $(\mathrm{F}=1.52$, $\mathrm{p}=0.166)$.

\section{Variation of resin constituents}

A total of 21 constituents were identified from resins of G. walla (Table 2, Figure 2) which could be classified into seven chemical classes, namely, vetispirane, selinene, cadinane, guaiene, eremophilane, 2-(2-phenylethyl)chromone derivatives and fatty acids. However, the presence of these constituents varied with population. Agarospirol and two 2-(2-phenylethyl)chromone derivatives were detected in all 90 trees sampled. The highest average agarospirol content (7.16 $\pm 3.56 \%$ ) was recorded from Kalatuwawa population followed by Suriyakanda (5.98 \pm $4.23 \%)$ and Horawala $(3.76 \pm 2.93 \%)$. The lowest average agarospirol content $(1.13 \pm 0.56 \%)$ was observed in Mirigama. The lowest recorded agarospirol content was $0.29 \%$ from a tree in Karandana population, while the highest content was $14.44 \%$ from Suriyakanda population.

Agarospirol, $\delta$-selinene, alloaromadendrene oxide, spathulenol and 2-(2-phenylethyl) chromone derivative were recorded from all nine populations. $\delta$-selinene, alloaromadendrene oxide and spathulenol were present in more than $85 \%$ of the total trees sampled. Linolelaidic acid and octadecenoic acid and $\beta$-guaiene were recorded from eight and seven populations 


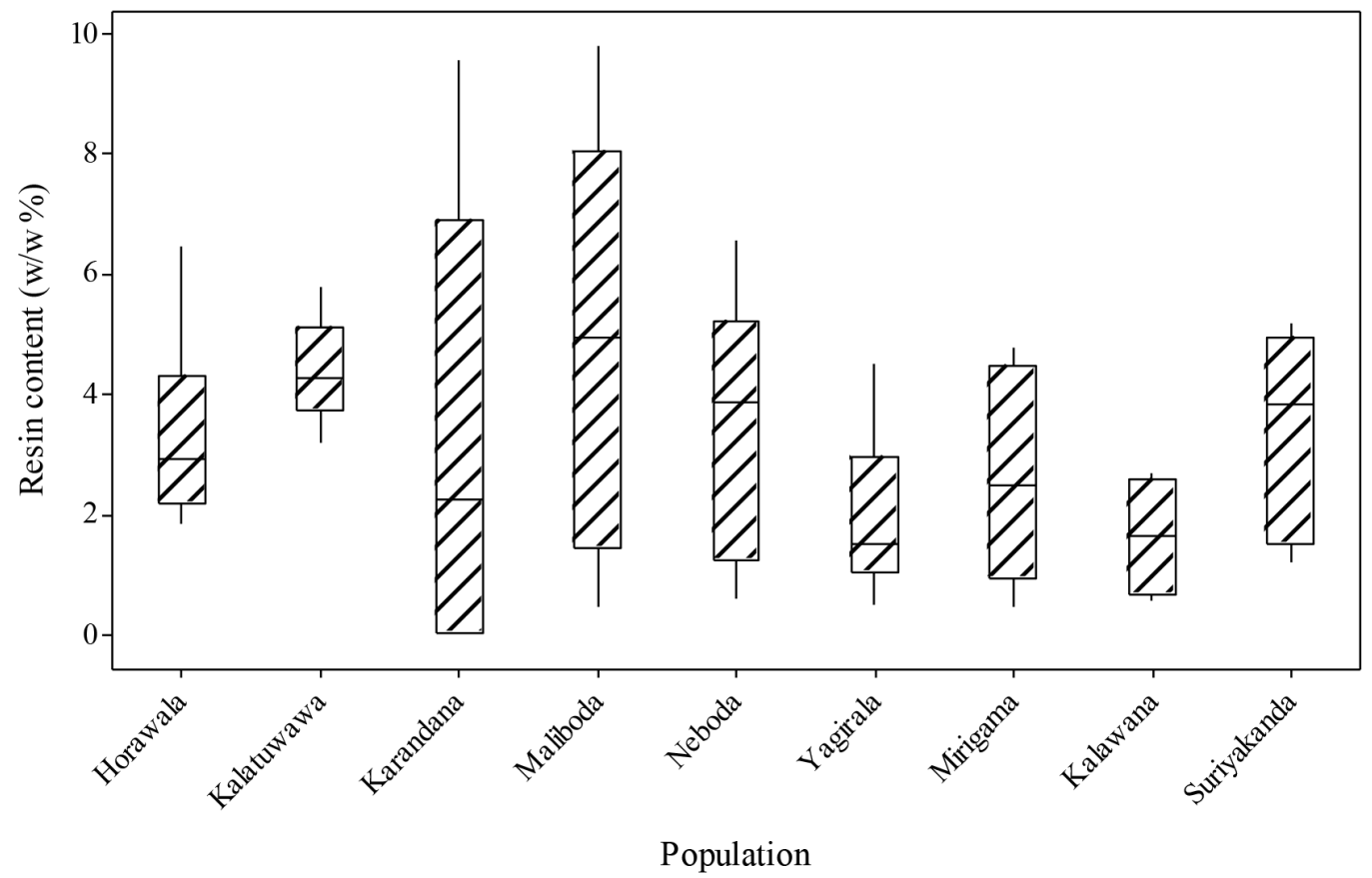

Figure 1 Average resin content with highest and lowest recorded values in selected Gyrinops walla populations

respectively (Table 2 ). The compound $\beta$-ionone (isomers) was detected only in trees from Karandana.

\section{Correlation of resin content and constituents}

Agarwood resin content showed significant correlation with 2-(2-phenylethyl)chromone derivative $(r=0.540, p=0.001)$, linolelaidic acid $(r=0.486, p=0.005)$ and oleic acid $(r=0.439$, $\mathrm{p}=0.012)$ (results not shown). Agarospirol did not show significant correlation with any of the compounds except with $\alpha$-guaiene $(r=0.363$, $\mathrm{p}=0.041) . \delta$-selinene was negatively correlated with $\delta$-cadinane $(r=-0.407, p=0.021)$ and positively correlated with alloaromadendrene oxide $(r=0.522, p=0.002)$. Significant correlation was shown by $\delta$-cadinane with $5(1 \mathrm{H})-2,4,6,7,8,8 \mathrm{a}-\mathrm{h}$ exahydro-3,8- dimethyl4-(1-methylethylidene)-,(8S-cis)- azulenone $(\mathrm{r}=0.532, \mathrm{p}=0.002)$, while $2(1 \mathrm{H})-3,5,6,7,8,8 \mathrm{a}-$ hexahydro-4,8a-dimethyl-6- (1-methylethenyl)naphthalenone was significantly correlated only with (-) guaiene-1(10),11-diene-15-ol $(\mathrm{r}=0.506, \mathrm{p}=0.003)$. Tetradecanoate was significantly correlated with alloaromadendrene oxide $(r=0.422, p=0.016)$, linolelaidic acid $(\mathrm{r}=0.579, \mathrm{p}=0.001)$, oleic acid $(\mathrm{r}=0.627$, $\mathrm{p}=0.000)$ and octadec-11-enoic acid $(\mathrm{r}=0.461$, $\mathrm{p}=0.008)$. Alloaromadendrene oxide had significant correlation with oleic acid $(r=0.473$, $\mathrm{p}=0.006)$ and octadecenoic acid $(\mathrm{r}=0.368$, $\mathrm{p}=0.038)$. Palmitate had significant correlation with 2-(2-phenyl) chromone derivative $(r=0.413$, $\mathrm{p}=0.019)$, linolelaidic acid $(\mathrm{r}=0.903, \mathrm{p}=0.000)$, oleic acid $(r=0.899, p=0.000)$ and octadecenoic acid $(\mathrm{r}=0.442, \mathrm{p}=0.001)$ while 2 - $(2-\mathrm{phenyl})$ chromone derivative was significantly correlated with linolelaidic acid $(\mathrm{r}=0.548 ; \mathrm{p}=0.001)$ and oleic acid $(r=0.377 ; p=0.033)$. Oleic acid also showed significant correlation with octadecenoic acid $(\mathrm{r}=0.445, \mathrm{p}=0.011)$.

Among the above compounds, oleic acid had the highest number of significant correlations, with six compounds. Linolelaidic acid and palmitate were significantly correlated with five compounds and tetradecanoate and alloaromadendrene oxide were significantly correlated with four compounds each. However, decahydro-2,2,4,8,-tetramethyl4,8-methanoazulen-9-ol, $\beta$-ionone (isomers), cloveone, $\beta$-caryophyllene and spathulenol did not show significant correlation with any other constituent. 


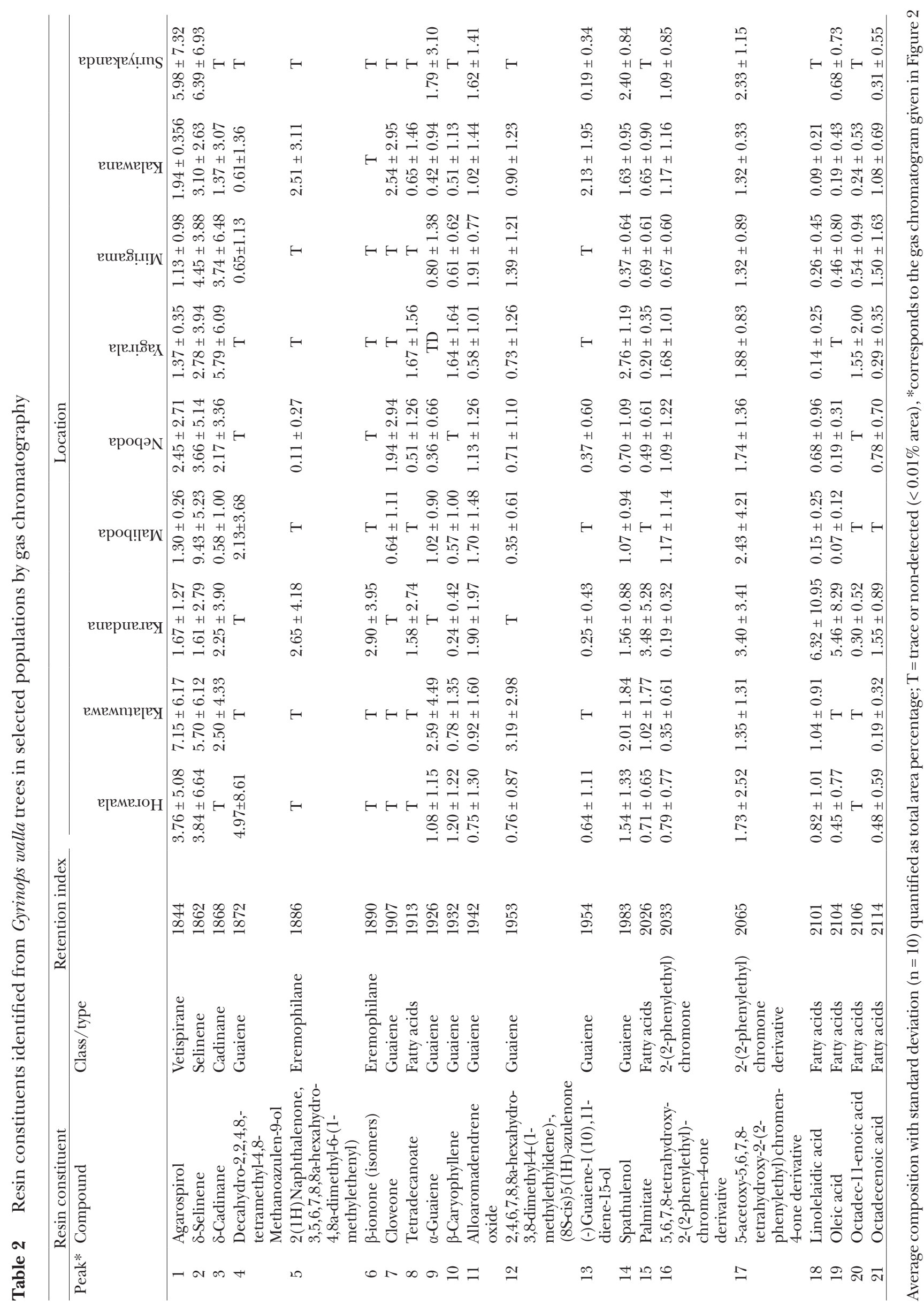




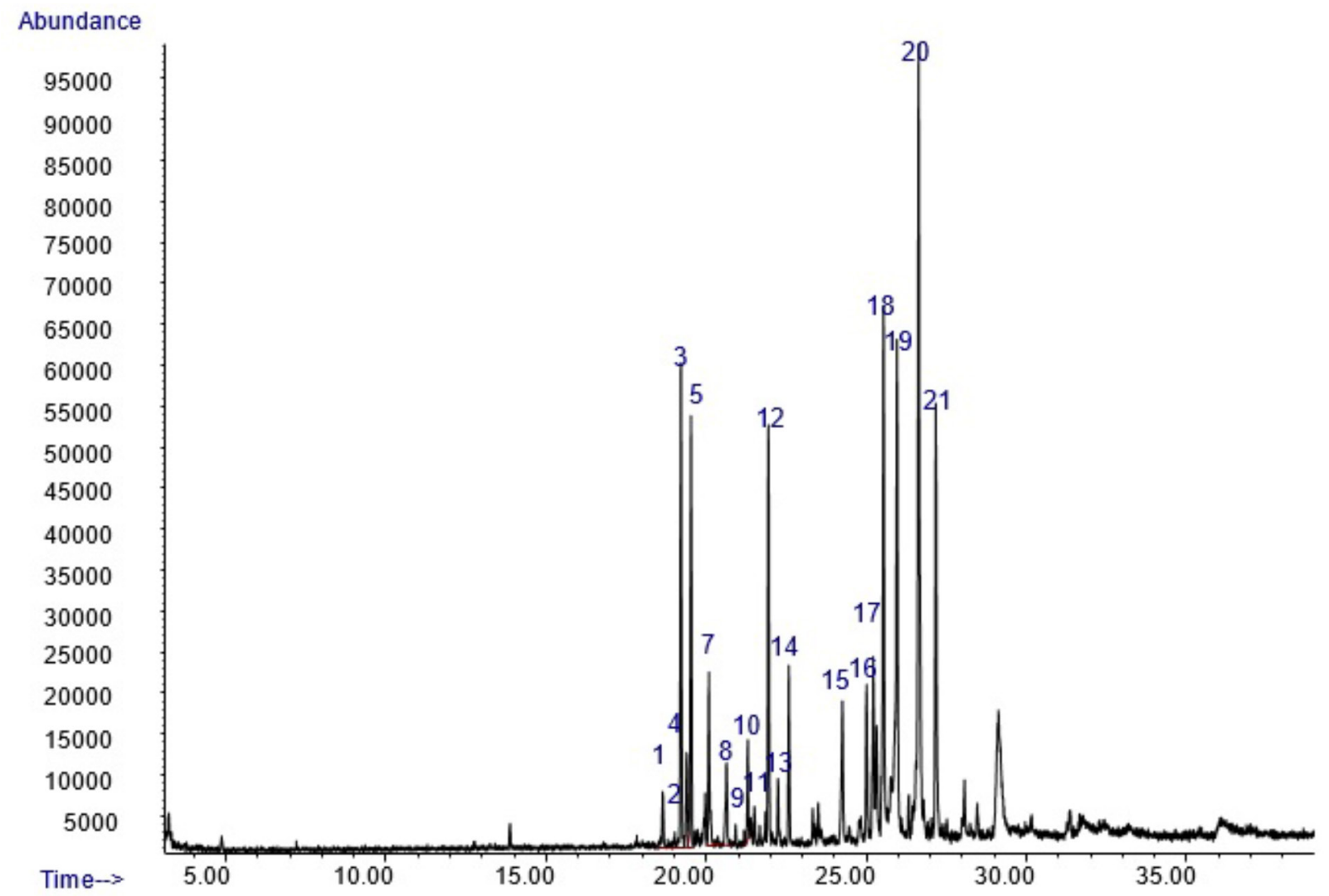

Figure 2 Typical gas chromatogram showing all the identified peaks listed in Table 2 for Gyrinops walla extracts of nine populations (sample KN01 from Kalawana population)

\section{DISCUSSION}

The present study reported low quantities of agarwood resins formed due to natural causes in G. walla trees growing in the natural environment. Blanchette (2003) observed a similar variation for agarwood resins extracted from the wild Aquilaria malaccensis trees. Age of the tree, growth parameters, genetics and environment factors play an important role in the natural formation of agarwood (Ng et al. 1997). However, Blanchette and van Beek (2005) reported that tree age, geographical and environmental variations are not important factors governing the resin formation. Since ages of the sampled trees were not known, growth parameters within a population were considered an indicator for age. Growth parameters such as diameter and height of $G$. walla did not show significant correlation with the resin content in this study. The present study did not find significant differences in resin content between tree populations.
In this study, solvent extraction was used due to the small sample size and more in-situ approach of natural formed resins. The hydrodistilled essential oils of this resin would have a different volatile component profile (Hashim et al. 2014). GC-MS analysis revealed that the agarwood resin of G. walla contained several principal aromatic compounds commonly found in agarwood resins of Aquilaria species. Chemical composition patterns identified agarospirol, $\delta$-selinene, alloaromadendrene oxide and spathulenol to be the key sesquiterpenes found in G. walla agarwood resins. The two unidentified species of 2-(2-phenylethyl) chromone derivatives were found to be common to all the samples. Linolelaidic and oleic acids were also reported in all the samples. A future study will investigate the composition of 2-(2-phenylethyl) chromone derivatives of $G$. walla, which can be used to differentiate the species and age of resin as reported by Lancaster and Espinosa (2012) and Mei et al. (2013). 
Resin composition varies with different trees of the same species (Yoneda et al. 1984, Takemoto et al. 2008). Guaienes and eudesmane sesquiterpenes in G. walla are also present in high quality agarwood resins (Ishihara et al. 1993). However, the current study did not report the presence of benzyl acetone, which is a major compound in certain agarwood essential oils extracted from Aquilaria species (Yang et al. 1988). Compounds such as $\beta$-agarofuran, $\alpha$-agarofuran and 10 -epi- $\gamma$-eudesmol which are indicators of high quality agarwood resins (Nor Azah et al. 2008, Pripdeevech et al. 2011), were also not found in G. walla trees sampled in this study. Current findings suggested that agarospirol can be used as marker compound for quality assurance of $G$. walla, in line with the industry standards presented by Kanwal (2016).

\section{CONGLUSIONS}

Variation in agarwood resin content and composition in G. walla was independent of the location and growth of the tree. Resin characteristics varied within a population as much as between populations, despite the diverse soil, climate and population factors. The presence of key agarwood resin compounds in G. walla supported the development of the tree as a source of agarwood, with unique characteristics for the species. These findings will be helpful in establishing an agarwood industry based on G. walla in Sri Lanka.

Gyrinops walla resins contained many compounds in common with Aquilaria and other Gyrinops species used as commercial agarwood. Agarospirol could be used as a quality parameter for $G$. walla resins while further investigation needs to be conducted into agarofurans, eudesmanes and guanines. A detailed study of 2-(2-phenylethyl) chromone derivatives could establish the identification parameters for G. walla which could help in restricting illegal harvesting of G. walla resources in Sri Lanka.

\section{ACKNOWLEDGEMENTS}

The authors acknowledge the Centre for Forestry and Environment of the University of Sri Jayewardenepura and financial assistance from National Research Council of Sri Lanka and Sadaharitha Plantations Limited under Private-
Public Partnership Program (Grant No. PPP12-57). Technical and editing support received from Professor Mary Boyce from Edith Cowan University Australia is much appreciated.

\section{REFERENCES}

AkHsan N, Mardji D \& Sutisna M. 2015. Response of Aquilaria acrocarpa to two species of Fusarium under two different cultivation systems. Journal of Tropical Forest Science 27: 447-455.

Blanchette RA. 2003. Deterioration in historic and archeological woods from terrestrial sites. Pp 328-347 in Koestler RJ et al. (eds) Art, Biology and Conservation: Biodeterioration of Works of Art. The Metropolitan Museum of Art, New York.

Blanchette RA \& VAN BEEK HH. 2005. Cultivated agarwood. US Patent 6,848,211 B2.

Dassanayake MD \& Fosberg FR. 1981. Flora of Sri Lanka. Volume II. Oxford and IBH Publishing Company, New Delhi.

Gianno R. 1986. The exploitation of resinous products in a lowland Malayan forest. Wallaceana 43: 3-6.

Hashim YZHY, Ismail NI \& AbBas P. 2014. Analysis of chemical compounds of agarwood oil from different species by gas chromatography mass spectometry (GCMS). IIUM Engineering Journal 15: 55-60. https://doi.org/10.31436/iiumej. v15i1.469.

Ishihara M, Tsuneya T \& Uneyama K. 1993. Components of the agarwood smoke on heating. Journal of Essential Oil Research 5: 419-423. https://doi.org/10.1080/1 0412905.1993 .9698252$.

Kanwal D. 2016. Agarwood market and trade. P 13 in Mohamed R (ed) Proceedings of the $2^{\text {nd }}$ International Scientific Symposium on Agarwood. 10-12 October 2016, Universiti Putra Malaysia, Serdang.

LANCASTER C \& Espinoza E. 2012. Evaluating agarwood products for 2-(2-phenylethyl)chromones using direct analysis in real time of flight mass spectrometry. Rapid Communications in Mass Spectrometry 26: 26492656. https://doi.org/10.1002/rcm.6388.

MeI WL, Yang DL, WANG H ET AL. 2013. Characterization and determination of 2-(2-phenylethyl)chromones in agarwood by GC-MS. Molecules 18: 12324-12345. https://doi.org/10.3390/molecules181012324.

Mohamed R, Jong PL \& ZaLi MS. 2010. Fungal diversity in wounded stems of Aquilaria malaccensis. Fungal Diversity 43: 67-74. https://doi.org/10.1007/s13225010-0039-z.

NAEF R. 2011. The volatile and semi-volatile constituents of agarwood, the infected heartwood of Aquilaria species: a review. Flavour and Fragrance Journal 26: 73-87. https://doi.org/10.1002/ffj.2034.

NG LT, Chang YS \& KAdir AA. 1997. A review on agar (gaharu) producing Aquilaria species. Journal of Tropical Forest Products 2: 272-285.

Nor Azah M, Chang YS, Mailina J et al. 2008. Comparison of chemical profiles of selected gaharu oils from Peninsular Malaysia. The Malaysian Journal of Analytical Sciences 12: 338-340.

Persoon GA. 2007. Agarwood: the life of a wounded tree. IIAS Newsletter 45: 24-25. 
Poain T \& Poain N. 2001. Interested Medicinal Plants. Offset Press Limited, Bangkok.

Pojanagaroon S \& KaEwrak C. 2005. Mechanical methods to stimulate aloes wood formation in Aquilaria crassna Pierre ex H. Lec. (Kritsana) trees. Acta Horticulturae 676: 161-166. https://doi.org/10.17660/ ActaHortic.2005.676.20.

Pripdeevech P, Khummueng W \& Park SK. 2011. Identification of odor-active components of agarwood essential oils from Thailand by soild phase microextractionGC-MS and GC-O. Journal of Essential Oil Research 23: 46-53. https://doi.org/10.1080/10412905.201 1.9700468

RAHMAN MA \& BASAK AC. 1980. Agar production in agar tree by artificial inoculation and wounding. Bano Biggyan Patrika 9: 87-93.

Rasool S \& Mohamed R. 2016. Understanding agarwood formation and its challenges. Pp 39-56 in Mohamed R (ed) Agarwood: Science Behind the Fragrance. Springer, Singapore. https://doi.org/10.1007/978981-10-0833-7_3.

Soehartono T \& Mardiastuti A. 1997. The current trade in gaharu in West Kalimantan. Biodiversitas Indonesia 1: 1-10.

Somasekaran T. 1997. Arjuna's Atlas. Arjuna Consulting Company, India.

Subasinghe SMCUP \& Hettiarachchi DS. 2013. Agarwood resin production and resin quality of Gyrinops walla Gaertn. International Journal of Agricultural Science 3: 357-362. https://doi.org/10.13140/2.1.4907.8405.

Subasinghe SMCUP \& Hettiarachchi DS. 2015. Characterisation of agarwood type resin of Gyrinops walla Gaertn. growing in selected populations in Sri Lanka. Industrial Crops and Products 69: 76-79. https://doi.org/10.1016/j.indcrop.2015.01.060.

Subasinghe SMCUP, Hettiarachchi DS \& Rathnamalala E. 2012. Agarwood-type resin from Gyrinops walla Gaertn.: a new discovery. Journal of Tropical Forestry and Environment 2: 43-48.
Tamuli P, Boruah P. Nath SC \& Samanta R. 2000. Fungi from diseased agarwood tree (Aquilaria agallocha Roxb.): two new records. Adventures of Forest Research India 22: 182-188.

Tajuddin SN, Aizal CM \& Yusoff MM. 2016. Resolution of complex sesquiterpene hydrocarbons in Aquilaria malaccensis volatile oils using gas chromatography technique. Pp 103-124 in Mohamed R (ed) Agarwood: Science Behind the Fragrance, Springer, Singapore. https://doi.org/10.1007/978-981-10-0833-7_7.

Takemoto H, Ito M, Shiraki T, Yagura T \& Honda G. 2008. Sedative effects of vapor inhalation of agarwood oil and spikenard extract and identification of their active components. Journal of Natural Medicines 62: 41-46. https://doi.org/10.1007/s11418-007-0177-0.

Turjaman M, Hidayat A \& Santoso E. 2016. Development of agarwood induction technology using endophytic fungi. Pp 57-71 in Mohamed R (ed) Agarwood: Science Behind the Fragrance. Springer, Singapore. https:// doi.org/10.1007/978-981-10-0833-7_4.

Van Beek HH \& Phillips D. 1999. Agarwood: Trade and CITES Implementation in Southeast Asia. TRAFFIC Southeast Asia, Malaysia.

YANG JS, WANG YL, Su YL, He CH, Zheng QT \& YANG J. 1988. Studies on the chemical constituents of Aquilaria sinensis (Luor) Gilg. III. Elucidation of the structure of the isobaimuxinol and isolation and identification of the constituents of lower boiling fraction of the volatile oil. Yao Xue Bao 24: 264-268.

Yoneda K, Yamagata E, Nakanishi T et al. 1984. Sesquiterpenoids in two different kinds of agarwood. Phytochemistry 23: 2068-2069. https:// doi.org/10.1016/S0031-9422(00)84976-6.

Wong YF, Chin ST, Perlmutter P \& Marriott PJ. 2015. Evaluation of comprehensive two-dimensional gas chromatography with accurate mass time-of-flight mass spectrometry for the metabolic profiling of plant-fungus interaction in Aquilaria malaccensis. Journal of Chromatography A 1387: 104-115. https:/ / doi.org/10.1016/j.chroma.2015.01.096. 